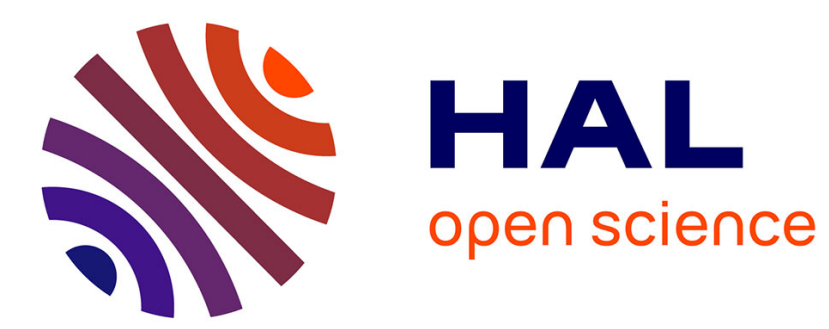

\title{
Do good deeds make bad people?
}

Sophie Clot, Gilles Grolleau, Lisette Ibanez

\section{To cite this version:}

Sophie Clot, Gilles Grolleau, Lisette Ibanez. Do good deeds make bad people?. 2011. hal-01485471

\section{HAL Id: hal-01485471 \\ https://hal.science/hal-01485471}

Preprint submitted on 8 Mar 2017

HAL is a multi-disciplinary open access archive for the deposit and dissemination of scientific research documents, whether they are published or not. The documents may come from teaching and research institutions in France or abroad, or from public or private research centers.
L'archive ouverte pluridisciplinaire HAL, est destinée au dépôt et à la diffusion de documents scientifiques de niveau recherche, publiés ou non, émanant des établissements d'enseignement et de recherche français ou étrangers, des laboratoires publics ou privés. 


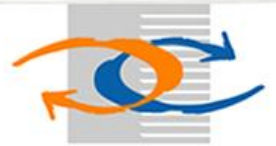

\section{A M E T A}

Laboratoire Montpelliérain d'Economie Théorique et Appliquée

U M R

Unité Mixte de Recherche

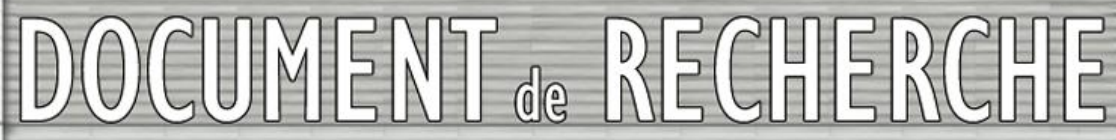

«Do Good Deeds Make Bad People? »

Sophie CLOT,

Gilles GROLLEAU, Lisette IBANEZ

DR $n^{\circ} 2011-21$

Unite de Formation et de Recherche d'Economie Avenue Raymond DUGRAND C.S. 79606 34960 MONTPELLIER Cedex 2 Tel : 33 (0) 467158495 Fax : 33(0)467158467 E-mail : lameta@lameta.univ-montp1.fr

\section{U, 1}




\title{
Do Good Deeds Make Bad People? ${ }^{1}$
}

\section{November 2011}

\author{
Sophie Clot \\ Montpellier SupAgro, UMR 1135 LAMETA, F-34000 Montpellier, France \\ Gilles Grolleau \\ Montpellier SupAgro, UMR 1135 LAMETA, F-34000 Montpellier, France
}

Lisette Ibanez

INRA, UMR 1135 LAMETA, F-34000 Montpellier, France

\begin{abstract}
A limited but growing literature contends that licensing can operate by committing to a virtuous act in a preceding choice, which reduces negative self-attributions associated with donating less or behaving less virtuously in the succeeding decision. Psychological research and behavioral economics strongly suggest that pre-existing intrinsic motivations of individuals play a major role in determining their subsequent choices when faced with a voluntary or mandatory virtuous 'act'. In this paper, we report the results of a pilot experimental study examining licensing effect in the environmental realm, using a 2 (mandatory or voluntary nature of the virtuous act) X 2 (intrinsically or non-intrinsically motivated individuals) between subjects design. We found that intrinsically motivated and non-intrinsically motivated subjects reacted adversely to the two policy scenarios. The licensing effect occurs when combining intrinsically (resp., non-intrinsically) motivated individuals and mandatory (resp. voluntary) conditions.
\end{abstract}

Key words: Licensing effect, environmental policies, behavioural incentives

JEL: Q50, D03, D04

\footnotetext{
${ }^{1}$ We gratefully acknowledge Nina Mazar, Sandrine Costa, Kate Farrow and Naoufel Mzoughi for constructive comments as well as participants at PERENE workgroup. We also thank Claire Mangani, Sébastien Roussel, Mélanie Jaeck and Peguy Ndodjang for having facilitated data collection. The usual disclaimer applies.
} 


\section{Do Good Deeds Make Bad People?}

\section{Introduction}

Does a commitment to a virtuous act encourage us to behave more virtuously or free us to behave less virtuously in subsequent acts? For example, Monbiot (2009) reports the story of a couple who 'earned so many vouchers from recycling at Tesco (a U.K. retailer) that they were able to fly to the Caribbean for a holiday. The greenhouse gases caused by these flights outweigh any likely savings from recycling hundreds or thousands of times over.' A small and recent, but growing body of experimental research (in numerous areas) has been devoted to understanding how people license themselves based on prior behaviors to pursue inconsistent goals (e.g., Khan and Dhar, 2006; Sachdeva et al., 2009; Mazar and Zhong, 2010; Chiou and al., 2011). For instance, Chiou and al. (2011) showed that smokers who believed they were taking a dietary supplement smoked more cigarettes than did controls, presumably because they think the supplements will protect them against smoking's ill effects. Nevertheless, as far as we know, no study has examined what happens if the 'virtuous' act is imposed on individuals or freely chosen by them. Psychological research and behavioral economics strongly suggest that pre-existing or intrinsic motivations play a major role in determining people's subsequent choices when faced with a voluntary or mandatory virtuous 'act'.

In this paper, we report the results of a pilot experimental study examining licensing effect in the environmental realm. Our 2 (mandatory or voluntary nature of the virtuous act) X 2 (intrinsically motivated or non-intrinsically motivated individuals) between-subjects design extends the literature in at least two dimensions. First, we test whether the licensing effect occurs when the virtuous act is voluntarily or mandatorily generated. Indeed, in the environmental realm people frequently face either an obligation to adopt some behaviors (e.g., speed limits to reduce pollution) or are simply encouraged to adopt others (e.g., Earth hour). Second, we examine the effect of the way the virtuous act is generated (voluntarily or mandatorily) according to whether individuals are either intrinsically motivated or not. We are aware of no other study of this type in the licensing effect literature.

A mixed set of results emerges from our experiment. We found that intrinsically motivated or nonintrinsically motivated subjects reacted adversely to the two policy scenarios. More precisely, the 
licensing effect occurs when combining intrinsically (non-intrinsically) motivated individuals and mandatory (voluntary) conditions.

The remainder of the paper is organized as follows. The next section overviews the related literature and introduces our hypotheses. Section 3 exposes the empirical strategy. The results are presented and discussed in section 4. Section 5 provides some policy implications and concludes.

\section{Overview of related literature and hypotheses}

According to prospect theory (Kahneman and Tversky, 1979), people do not have absolute preference, but rather preferences that are relative to some anchor point. If one of the key contributions has been to empirically prove that preferences are endogenous, the relation between passed actions and subsequent decisions remains largely unexplored.

The idea of a licensing effect has been emerging recently. The literature in marketing and psychology hold several recent works (Table 1 ) showing that moral licensing can operate by committing to a virtuous act in a preceding choice, which reduces negative self-attributions associated with donating less or behaving less virtuously in the succeeding decision.

Khan and Dhar (2006) studied individuals' decision process in terms of luxury products consumption. They first found out in a pretest that luxury products are associated with less moral attributes. They then demonstrated how an initial situation referring to a charity act, could influence preferences for unnecessary or extravagant items in subsequent decisions. The results of their experience show that preference for luxury items was significantly higher in the case of a preceding charity action (license condition), than in the case where no prior charity action (control condition) had to be undertaken first (i.e. $57.4 \%$ selected a luxury item in the license condition vs. $27.7 \%$ in the control condition). Also, participants rated themselves significantly more positively on a 7 points scale within four attributes $^{2}$ (i.e. "I am compassionate", "I am sympathetic", "I am warm", and "I am helpful”) in the licensing condition, meaning that an initial altruistic intent boosts the self-concept and may liberate people to choose more indulgent options (i.e. average of feelings was 5.76 in the license condition vs. 4.79 in the control condition).

$2 \quad$ These items were utilized because they indicated a high degree of reliability in terms of coefficient alpha (Cronbach's $\alpha=0.84)$ 
Studying this behavioural mechanism in the case of altruism and charity donation, Sachdeva, lliev and Medin (2009) found that moral regulation mechanisms might happen in the reverse order and create a compensation effect (behaving 'indulgently' first and then compensate with a more virtuous act). The authors hypothesized that priming people with positive and negative traits in a first stage will affect subsequent moral behaviour in terms of donation to a charity found. Their results show that among the 46 individuals who participated in the survey, those who wrote something positive about themselves gave one fifth as much as those who wrote a story referring to negative traits (average amount of donation was $\$ 1.07$ over $\$ 10$ in the positive condition vs. $\$ 5.30$ in the negative condition). They observed that if people feel as if they have been less ethical than they should, they might compensate by behaving more morally in a subsequent context. The authors included this set of compensatory behaviours under a blanket term of "moral cleansing", which refers to actions people engage in when their moral self-value has been threatened.

Mazar and Zhong (2010) examined the moral licensing effect in the field of the environment. The authors addressed two main questions: 1) the impact of exposure vs. purchase on moral licensing effect and 2) how far the regulation process may lead people to behave unethically. First, the results show that participants who were merely exposed to the green store shared more money in the dictator game than those who were merely exposed to the conventional store (average amount shared was $\$ 2.18$ over $\$ 6$ in the green store exposure condition vs. $\$ 1.59$ in the conventional store exposure condition), whereas participants who had purchased in the green store shared less money than those who purchased in the conventional store (average amount shared was $\$ 1.76$ over $\$ 6$ in the green store purchase condition vs. \$2.12 in the conventional store purchase condition). Second, the results also demonstrate that participants who chose to buy products from the green array were more likely to purposefully behave dishonestly such as cheating and stealing in a subsequent task. Mazar and Zong (2010) concluded that green products can establish enough moral capital to encourage clear transgressions such as lying and stealing.

We could resume this literature review in three main points. First, a licensing effect does occur and it matters in various domains. Second, it can happen in the reverse order ('compensation effect'). Third, when a high level of moral capital is 'credited', it can even lead to dishonesty and encourage clear moral transgressions. 
Table 1. Experimental studies devoted to the licensing effect

\begin{tabular}{|c|c|c|c|c|c|c|}
\hline $\begin{array}{l}\text { Authors and } \\
\text { publication year }\end{array}$ & Khan and Dhar (2006) & $\begin{array}{l}\text { Sachdeva, Lliev and } \\
\text { Medin (2009) }\end{array}$ & $\begin{array}{l}\text { Mazar and Zhong } \\
\text { (2010) }\end{array}$ & $\begin{array}{l}\text { Mazar and Zhong } \\
\text { (2010) }\end{array}$ & $\begin{array}{l}\text { Chiou, Wan, Wu and Lee } \\
\text { (2011) }\end{array}$ & $\begin{array}{l}\text { Jordan, Mullen, and } \\
\text { Murnighan (2011) }\end{array}$ \\
\hline $\begin{array}{l}\text { Experimental design: } \\
\text { virtuous act and } \\
\text { subsequent choices }\end{array}$ & $\begin{array}{l}\text { Single-factor (help a } \\
\text { friend vs. control) } \\
\text { between-participants } \\
\text { design, followed by a } \\
\text { dictator game }\end{array}$ & $\begin{array}{l}\text { Two-factors (personal } \\
\text { story writing using: } \\
\text { negative traits vs } \\
\text { positive traits vs } \\
\text { neutral traits), } \\
\text { between-participants } \\
\text { design, followed by a } \\
\text { dictator game }\end{array}$ & $\begin{array}{l}2 \text { (store: conventional } \\
\text { vs. green) x } 2 \text { (action: } \\
\text { mere exposure vs. } \\
\text { purchase) between- } \\
\text { participants design, } \\
\text { followed by a dictator } \\
\text { game }\end{array}$ & $\begin{array}{l}\text { Single-factor (store: } \\
\text { conventional vs. } \\
\text { green) between- } \\
\text { participants design, } \\
\text { followed by a lying } \\
\text { and stealing games }\end{array}$ & $\begin{array}{l}\text { Single-factor (credentials: } \\
\text { with or without) } \\
\text { between-participants } \\
\text { design }\end{array}$ & $\begin{array}{l}2 \text { (target: self, other) } \times 2 \\
\text { (recall: moral, immoral) } \\
\text { between-participants } \\
\text { design }\end{array}$ \\
\hline $\begin{array}{l}\text { Type and nature of } \\
\text { subjects }\end{array}$ & 80 Students & 46 Students & 156 Students & 90 students & 80 Students & 168 Students \\
\hline Main results & $\begin{array}{l}\text { Participants in the } \\
\text { licensing conditions } \\
\text { gave less than } \\
\text { participants in the } \\
\text { control group (Mean of } \\
\text { donation= } \$ 1.20 \text { over } \\
\$ 2 \text { vs } \$ 1.70 \text { ) }\end{array}$ & $\begin{array}{l}\text { Participants who wrote } \\
\text { a positive story about } \\
\text { themselves gave less } \\
\text { than the two other } \\
\text { groups (Mean of } \\
\text { donation= } \$ 1.07 \text { over } \\
\$ 10 \text { vs } \$ 5.30 \text { for those } \\
\text { in the negative } \\
\text { condition and } \$ 2.71 \text { for } \\
\text { those in the neutral } \\
\text { condition) }\end{array}$ & $\begin{array}{l}\text { Mere exposure to } \\
\text { green products } \\
\text { increases pro social } \\
\text { behavior whereas } \\
\text { purchasing them } \\
\text { licenses (Mean of } \\
\text { donation=\$2.12 over } \\
\$ 6 \text { vs } \$ 1.76 \text { ) }\end{array}$ & $\begin{array}{l}\text { Participants in the } \\
\text { green store took in } \\
\text { total (due to both } \\
\text { lying and stealing) on } \\
\text { average } \$ 0.83 \text { more } \\
\text { than those in the } \\
\text { conventional store } \\
\text { (over } \$ 2.93 \text { ). }\end{array}$ & $\begin{array}{l}\text { Credentials created by } \\
\text { vitamins use can increase } \\
\text { smokers' comfort with } \\
\text { consuming more } \\
\text { cigarettes. } \\
\text { Increased invulnerability } \\
\text { is associated with } \\
\text { attitudes towards dietary } \\
\text { supplements ( } r=0.39, \mathrm{P}< \\
0.001 \text { ). }\end{array}$ & $\begin{array}{l}\text { Recalling (im)moral } \\
\text { behavior affects an } \\
\text { individual's reported } \\
\text { moral behavior and moral } \\
\text { intentions but also affects } \\
\text { an individual's actual } \\
\text { (im)moral behavior. The } \\
\text { morality ratings are } \\
\text { positively correlated with } \\
\text { the magnitude of } \\
\text { cheating ( } r=.34, p=.002 \text { ) } \\
\text { These effects did not } \\
\text { emerge when recalling } \\
\text { other's im(moral) } \\
\text { behavior. }\end{array}$ \\
\hline
\end{tabular}




\section{Behavioral hypotheses}

Rewarding or imposing constraints on individuals can push them to adopt behaviors that will not be adopted otherwise. In plausible circumstances, demonstration of authority such as rules and laws could build norms, by suggesting that an event is important enough to justify a costly intervention (Nyborg, 1999). Nevertheless, if intrinsic motivations preexist, introducing additional external incentives (e.g. authoritarian decision; monetary rewards) to reinforce the intrinsically motivated behavior can backfire (Frey and Oberholzer-Gee, 1997; Frey and Jegen, 2001; Bowles, 2008). A growing literature argues that external interventions crowd out intrinsic motivation (Bénabou and Tirole, 2006) and some empirical evidence has been given by various authors in support (e.g., Gneezy and Rustichini, 2000; Vollan, 2008; Bowles, 2008). The crowding out effect is more likely to occur when external interventions are controlling (rather than supportive), the degree of participants' selfdetermination is low (rather than high) and the level of trust and reciprocity within a society is low (Vollan, 2008). For instance, Chang and Lai (1999), found that a rise in monitoring intensity tends to lower, rather than enhance, work effort. In relation with the previous literature, we formulate our two main hypotheses:

H1: A mandatory 'virtuous act' by intrinsically (non-intrinsically) motivated individuals increases (decreases) the licensing effect.

H2: A voluntary 'virtuous act' by intrinsically (non-intrinsically) motivated individuals decreases (increases) the licensing effect.

The design of our experiment is presented in table 2. We investigate how two subgroups of the population (intrinsically motivated vs. non-intrinsically motivated) react to the way the 'good deed' (mandatorily vs. voluntarily) is generated. We explore whether the licensing effect occurs and draw some policy implications regarding the use of voluntary or mandatory instruments. 
Table 2. Between subjects research design used to control for the conditions leading to the licensing effect

\begin{tabular}{|l|c|c|}
\hline \multirow{2}{*}{ Scenarios } & \multicolumn{2}{|c|}{ Conditions } \\
\cline { 2 - 3 } & Intrinsically motivated individuals & Non-intrinsically motivated individuals \\
\hline Mandatory 'virtuous act' & Licensing effect & No licensing effect \\
\hline Voluntary 'virtuous act' & No licensing effect & Licensing effect \\
\hline
\end{tabular}

\section{Experimental design}

In the spring of 2011, we conducted a set of experiments with students at high education institutions of Montpellier (South of France) from both business-related majors and environmental-related majors. In line with previous analyses (Frank, 2003), we assume that students self-select and it is well-known that students choose their majors at least partly because of their interests for the studied domains ${ }^{3}$. We contend that individuals enrolled in environmental-related majors are intrinsically motivated regarding environmental issues whereas individuals enrolled in businessrelated majors are non-intrinsically motivated regarding the same issues ${ }^{4}$. These two types of students should allow us to capture the potential effect of intrinsic motivation over our experimental design. Participants were not informed previously that they will participate in an experiment to avoid any selection bias. Students were already there for their lectures and the experiment was presented as a classroom activity at the end of the lecture. Experiments lasted less than $5 \mathrm{mn}$. Participants were not informed about the nature of the experiment we would be conducting or the treatment to which they would be assigned. In each 30 students group, students were promised a $30 €$ prize by drawing lots. This incentive compatibility method was preferred because of the well-known bias leading people to overweight small probabilities (Chen and Jia, 2005; Burns, Chiu and Wu, 2010).

A subject's experience followed four steps. First, all subjects received a copy of the instructions and the monitor read the instructions aloud. Second, all subjects received closed envelopes containing a

\footnotetext{
3 This point is consistent with Frank's finding (2003). Frank's (2003) survey on Cornell graduates show that 88 percent of socially concerned respondents would prefer a job for the American Cancer Society rather than for Camel Cigarettes with an average compensating wage premium of about $\$ 24.000$ per year. Cornell graduates were invited to choose between pairs of hypothetical jobs where the job nature was the same but the employers' social responsibility reputation was different.

$4 \quad$ For sake of exposition, we distinguish intrinsically motivated and non-intrinsically motivated but we are conscious that the reality is more nuanced. In short, we contend that business-students also truly care about the environment, but maybe not as strongly as environment-students.
} 
questionnaire corresponding either to (i) a dictator game where they can share the $30 €$ prize with an environmental union without any previous commitment to a virtuous act (=control group); (ii) the possibility to commit voluntarily to an environmentally friendly act followed by the previously described dictator game (=treatment one); (iii) the mandatory act followed by the previously described dictator game (=treatment two). Table 3 gives an overview of our experimental design. Both mandatory and voluntary acts were based on cheap talk framing.

- The voluntary framing states: $\ll 1 /$ You have the opportunity to get involved in a pro environmental program one hour per week during a month. Do you wish to engage? => Yes or No. 2/ On a 1 to 9 scale, select the satisfaction level that best describes yours after that decision >>

- The mandatory framing states: $<1 /$ Your University decides to settle a mandatory pro environmental program in which you have to get involved one hour per week during a month. 2/ On a 1 to 9 scale, select the satisfaction level that best describes yours after that decision $>$.

The satisfaction scale's records aimed mostly at making sure that subjects put some attention on the imagined act. Since both conditions (mandatory and voluntary) are based on cheap talk, it should theoretically not make any difference in participants' willingness to donate. Nevertheless, we believe that imagining committing to a virtuous act is sufficient to induce a licensing effect. Beside, everything was done to avoid attracting the attention of subjects regarding questionnaire variations (e.g., identical envelopes, similar questionnaire size, and identical questionnaires on a given row). Third, participants were given one minute and thirty seconds to fill in the questionnaires anonymously. After the time elapsed, sheets were collected and the winning number was announced. The amount corresponding to the winner's decision was put inside an empty envelope and given to the winner by the professor at the end of the lecture.

Table 3. Experimental Design

\begin{tabular}{|c|c|c|}
\hline Control & $\begin{array}{c}\text { Treatment 1 } \\
\text { Mandatory condition } \\
\text { A pro environmental deed has to } \\
\text { be done }\end{array}$ & $\begin{array}{c}\text { Treatment 2 } \\
\text { Voluntary condition } \\
\text { A pro environmental deed is } \\
\text { proposed } \\
\text { (1=Accept; 2=Refuse) }\end{array}$ \\
\hline
\end{tabular}

Dictator Game. (Measuring the Willingness to Donate)

Part of the potential earnings to be given in favor of a pro environmental project 


\section{Results}

A total of 185 Master students participated in this study, including 123 subjects from businessrelated majors (Mean age $=22.70, S E M^{5}=0.20$ ) and 62 students from environmental-related majors (Mean age $=20.77$, SEM $^{3}=0.11$ ). All subjects were unfamiliar with experimental economics. Gender characteristics proved to be well balanced across treatment groups. Below, we summarize our two main results (figures are presented in table 4).

R1: Intrinsically motivated individuals donated significantly less than non-intrinsically motivated individuals after a mandatory virtuous act. Difference is significant at the $5 \%$ level, $t(61)=2,569$, $p=0,012$. This supports our first hypothesis $H 1$.

R2: Intrinsically motivated individuals donated significantly more than non-intrinsically motivated individuals after a voluntary virtuous act. Difference is significant at the $5 \%$ level, $t(30)=2,214$, $\mathrm{p}=0,034$. This supports our second hypothesis $\mathrm{H} 2$.

Our first main result indicates that licensing effect happened in the mandatory scenario with intrinsically motivated individuals, whereas our second main result points out that licensing effect happened in the voluntary scenario with non-intrinsically motivated individuals. In sum, intrinsically

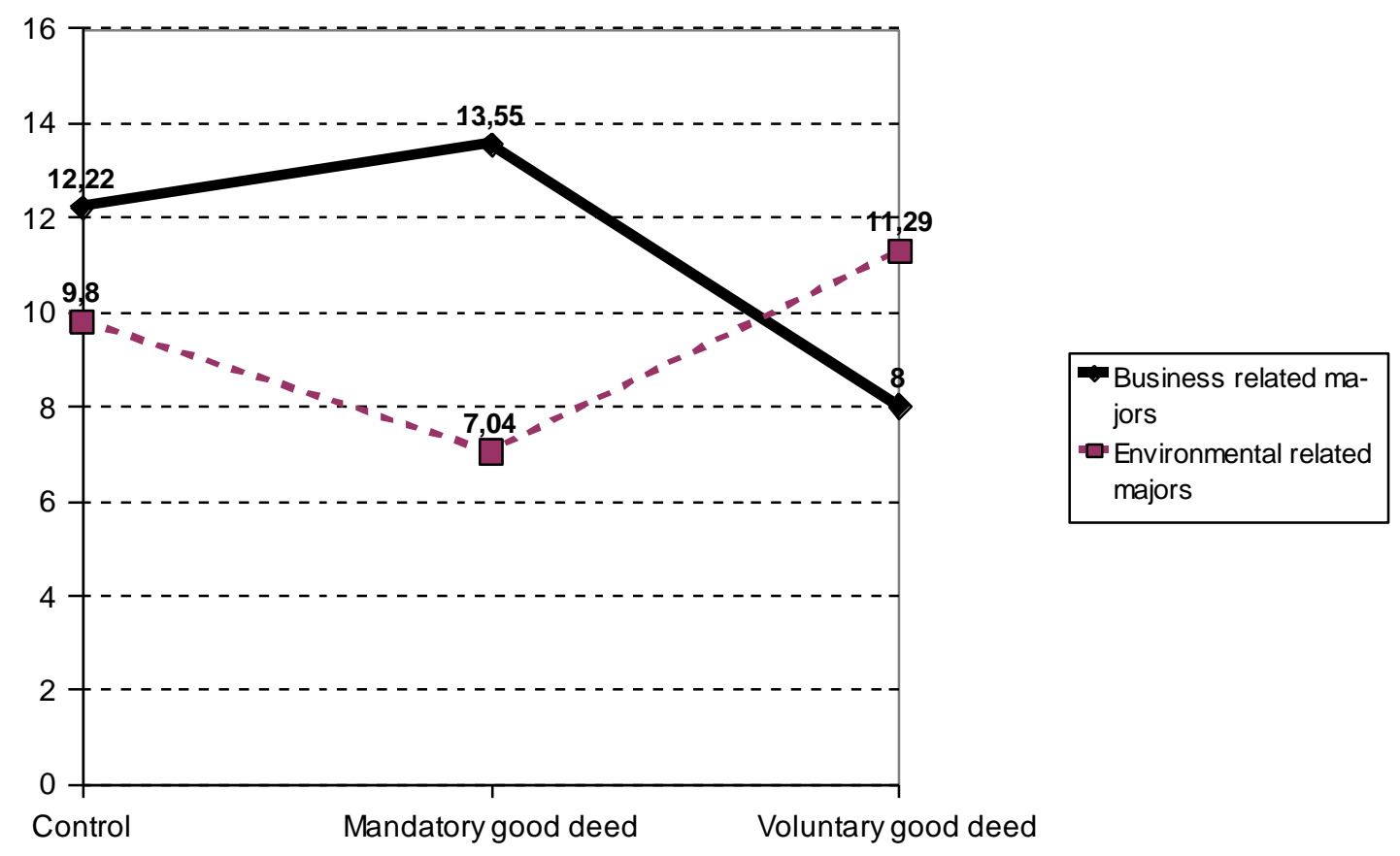

Figure 1. Average willingness to donate to the environmental union under different conditions

5 Standard Error of the Mean 
and non-intrinsically motivated individuals reacted adversely to the two policy designs. Figure 1 illustrates our findings.

Table 4 summarizes the results. The columns in table 3 correspond to different outcomes (willingness to donate), each of which is recorded separately among intrinsically vs. non-intrinsically motivated individuals. The top row reports means for the control group (neither voluntary nor mandatory virtuous act in a first stage). The next two rows explore means for the treatment one (voluntary virtuous act first), separating results in two lines: those who refused to commit to the virtuous act and then, those who accepted to commit. The final row reports means for treatment two (mandatory virtuous act first).

Table 4. Average willingness to donate to the environmental union and $\mathrm{SEM}^{3}$ under different conditions

\begin{tabular}{|c|c|c|}
\hline & $\begin{array}{c}\text { Environmental related majors } \\
\text { (Intrinsically motivated individuals) }\end{array}$ & $\begin{array}{c}\text { Business related majors } \\
\text { (Non-intrinsically motivated individuals) }\end{array}$ \\
\hline \multicolumn{3}{|c|}{ Control group } \\
\hline No virtuous act & $9,8(2,354)$ & $12,22(1,657)$ \\
\hline \multicolumn{3}{|c|}{ Voluntary condition (Treatment one) } \\
\hline $\begin{array}{c}\text { No virtuous act } \\
\text { (refuse) }\end{array}$ & $12,13(4,23)$ & $10,523(2,54)$ \\
\hline $\begin{array}{c}\text { Voluntary } \\
\text { virtuous act }\end{array}$ & $10,77(2,181)$ & $5,21(1,448)^{7}$ \\
\hline \multicolumn{2}{|c|}{} & Mandatory condition (Treatment two) \\
\hline $\begin{array}{c}\text { Mandatory } \\
\text { virtuous act }\end{array}$ & $7,04(1,884)$ & $13,55(1,518)$ \\
\hline
\end{tabular}

\section{Policy implications and conclusion}

First of all, our contribution is an additional stone supporting the fact that actions must not be considered in isolation but as influencing each other. The influence is not only related to the nature of the action (good versus bad deed) but also the way it is generated. We have shown that the licensing effect is influenced by the way the 'virtuous' act is generated according to whether individuals are intrinsically motivated or not.

\footnotetext{
6 Participation rate in the voluntary condition was slightly higher for intrinsically motivated individuals than for nonintrinsically motivated individuals ( $62 \%$ vs. $50 \%$ ).

$7 \quad$ We checked for a revenue effect, but low income ratio in this condition is equivalent to the whole sample (low income $=42 \%$ and high income $=58 \%$ vs $46 \%$ and $54 \%$ for the whole sample)
} 
The study aimed to experimentally test for conditions that are assumed to influence the licensing effect. We conclude that the presence of intrinsic motivation and the way the virtuous act is generated (voluntarily or mandatorily) are two important conditions explaining the occurrence of licensing effect. We found that intrinsically motivated individuals donated significantly less than nonintrinsically motivated individuals after a mandatory virtuous act. Conversely, intrinsically motivated individuals donated significantly more than non-intrinsically motivated individuals after a voluntary virtuous act. The licensing effect arises when combining intrinsically (non- intrinsically) motivated individuals and mandatory (voluntary) conditions. Overall, intrinsically and non-intrinsically motivated individuals reacted adversely to the treatment variables. Mandatory condition does not work well with intrinsically motivated individuals but it does work well with non-intrinsically motivated individuals. The voluntary scenario performs better with intrinsically motivated individuals but licenses non-intrinsically motivated individuals.

The main implication of these findings suggests the need to target policies according to population subgroups and avoid 'one-size-fits-all' policies in the environmental realm. Indeed, it seems necessary to characterize and elicit whether subgroups of the population are intrinsically motivated to tailor policy instruments accordingly. Further research may not only suggest methods to avoid licensing effect, but also hold the promise of helping to design settings that foster tailored policies. Also, this challenging point may raise equity issues where subgroups would face different instruments.

\section{References}

Bénabou, R., Tirole, J. (2006), "Incentives and Prosocial Behavior", The American Economic Review, 96(5), 1652-1678.

Bowles, S. (2008), "Policies designed for self-interested citizens may undermine the moral sentiments': evidence from economic experiments", Science, 320 (5883), 1605-1609.

Burns, Z., Chiu, A., Wu, G. (2010), “Overweighting of Small Probabilities", Wiley Encyclopedia of Operations Research and Management Science, 19pp.

Chang, J., Lai, C. (1999), "Local environmental control and institutional crowding out", European Journal of Political Economy, 15(2), 297-310.

Chen, R., Jia, J. (2005), “Consumer Choices Under Small Probabilities: Overweighting or Underweighting?", Marketing Letters, 16(1), 5-18. 
Chiou, W.-B., Wan, C.-S., Wu, W.-H. and Lee, K.-T. (2011), "A randomized experiment to examine unintended consequences of dietary supplement use among daily smokers: taking supplements reduces self-regulation of smoking", Addiction, 106(12), 2221-2228.

Frank, R.H., (2003), "What Price the Moral High Ground? Ethical Dilemmas in Competitive Environments", Princeton University Press, 224 pp.

Frey, B. Oberholzer-Gee, F. (1997), "The Cost of Price Incentives: An Empirical Analysis of Motivation Crowding- Out", The American Economic Review, .87(4), 746-755.

Frey, B., Jegen, R. (2001), “Motivation Crowding Theory", Journal of Economic Survey, 15(5), 589-611. Jordan, Mullen, and Murnighan (2011), "Striving for the moral self: the effects of recalling past moral actions on future moral behavior", Personality \& Social Psychology Bulletin, 37(5), 701-713.

Khan, U., Dhar, R. (2006), "Licensing Effect in Consumer Choice”, Journal of Marketing Research, 43 (2), 357-365.

Mazar, N., Zhong, C. (2010), “Do Green Products Make Us Better People?”, Psychological Science, 21(4), 494-498.

Monbiot, G. (2009) "We cannot change the world by changing our buying habits", George Monbiot's Blog, http://www.guardian.co.uk/environment/georgemonbiot/2009/nov/06/green-consumerism.

Nyborg, K. (1999), “Informational Aspect of Environment Policy Deserves More Attention: Comment on the Paper by Frey", Journal of Consumer Policy, 22 (4), 419-427.

Sachdeva, S., lliev, R., Medin, D. (2009), "Sinning Saints and Saintly Sinners: The paradox of Moral Self-Regulation", Psychological Science, 20 (4), 523-528.

Gneezy, U., Rustichini, A. (2000), "Pay enough or don't pay at all”, The Quarterly Journal of Economics, 115 (3), 791-810.

Kahneman, D., Tversky, A. (1979), "Prospect Theory: An Analysis of Decision under Risk", Econometrica, 47 (2), 263-292.

Vollan, B. (2008), "Socio-ecological explanations for crowding-out effects from economic field experiments in southern Africa," Ecological Economics, 67(4), 560-573. 


\title{
Documents de Recherche parus en $2011^{1}$
}

\author{
DR n²011 - 01 : Solenn LEPLAY, Sophie THOYER \\ «Synergy effects of international policy instruments to reduce \\ deforestation: a cross-country panel data analysis » \\ DR n²011 - 02 : Solenn LEPLAY, Jonah BUSCH, Philippe DELACOTE, Sophie \\ THOYER \\ « Implementation of national and international REDD \\ mechanism under alternative payments for environemtal \\ services: theory and illustration from Sumatra » \\ DR n²011 - 03 : $\quad$ Stéphanie AULONG, Robert KAST \\ «A conceptual framework to assess vulnerability. Application to \\ global change stressors on South Indian farmers » \\ DR n²011 - 04 : Nicolas QUEROU, Raphael SOUBEYRAN \\ « Voting Rules in Bargaining with Costly Persistent Recognition » \\ DR n²011 - 05 : $\quad$ Pierre COURTOIS, Rabia NESSAH, Tarik TAZDAÏT \\ «How to play the games? Nash versus Berge behavior rules» \\ DR n²011 - 06 : Pierre COURTOIS, Tarik TAZDAÏT \\ « Learning to trust strangers: an evolutionary perspective » \\ DR n²011 - 07 : $\quad$ Pierre COURTOIS, Tarik TAZDAÏT \\ « Bargaining over a climate deal: is it worse to wait and see? » \\ DR n²011 - 08 : Mathieu COUTTENIER, Raphael SOUBEYRAN \\ « Diplomatic Intervention in Civil War: Trade for All or Trade for \\ One?» \\ DR n²011 - 09: Edmond BARANES, Jean-Christophe POUDOU \\ «Internet access and investment incentives for broadband service \\ providers » \\ DR n²011 - 10 : Sadek MELHEM, Michel TERRAZA, Mohamed CHIKHI \\ «Cyclical Mackey Glass Model for Oil Bull Seasonal »
}

\footnotetext{
${ }^{1}$ La liste intégrale des Documents de Travail du LAMETA parus depuis 1997 est disponible sur le site internet : http://www.lameta.univ-montp1.fr
} 
DR n²011 - 11: Marianne LEFEBVRE, Sophie THOYER, Mabel TIDBALL, Marc WILLINGER

«Sharing rules for a Common-Pool Resource with private alternatives »

DR n²011-12: $\quad$ Ahmed ENNASRI, Marc WILLINGER

«Managerial incentives under competitive pressure: Experimental investigation »

DR n²011 - 13 : $\quad$ Sadek MELHEM, Abdul Salam DIALLO, Michel TERRAZA

« Hypothesis of Currency Basket Pricing of Crude Oil: An Iranian Perspective »

DR n²011 - 14: Marianne LEFEBVRE, Lata GANGADHARAN, Sophie THOYER «Do Security-differentiated Water Rights Improve Efficiency? »

DR n²011 - 15: Antoine BERETTI, Charles FIGUIERES, Gilles GROLLEAU « Using Money to Motivate Both 'Saints' and 'Sinners' : A Field Experiment On Motivational Crowding-Out»

DR n²011 - 16: Jérémy CELSE

«Damaging the Perfect Image of Athletes: How Sport Promotes Envy»

DR n²011 - 17: Charles FIGUIERES, Estelle MIDLER

«Deforestation as an externality problem to be solved efficiently and fairly »

DR n²011 - 18 : Rachida HENNANI, Michel TERRAZA

«Etude de la performance d'une Value-at-Risk chaotique pour l'indice CAC 40 »

DR n²011 - 19: Charles N. NOUSSAIR, Marc WILLINGER

«Mixed strategies in an unprofitable game: an experiment »

DR n²011 - 20 : Mohamed ALI BCHIR, Anne ROZAN, Marc WILLINGER

«Does higher trust lead to higher performance? An experimental investigation »

DR n²011 - 21: Sophie CLOT, Gilles GROLLEAU, Lisette IBANEZ

«Do Good Deeds Make Bad People?» 
Contact :

Stéphane MUSSARD : $\quad$ mussard@lameta.univ-montp1.fr 


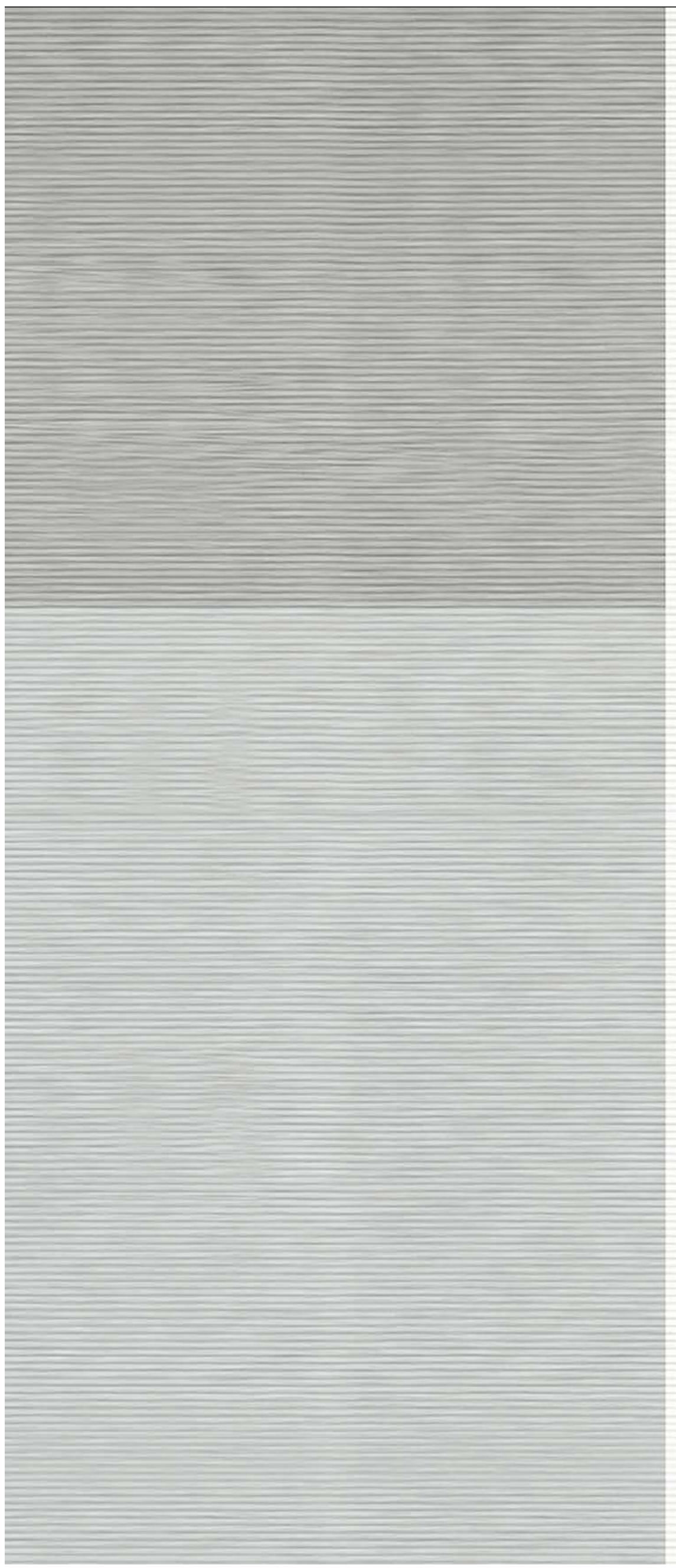

